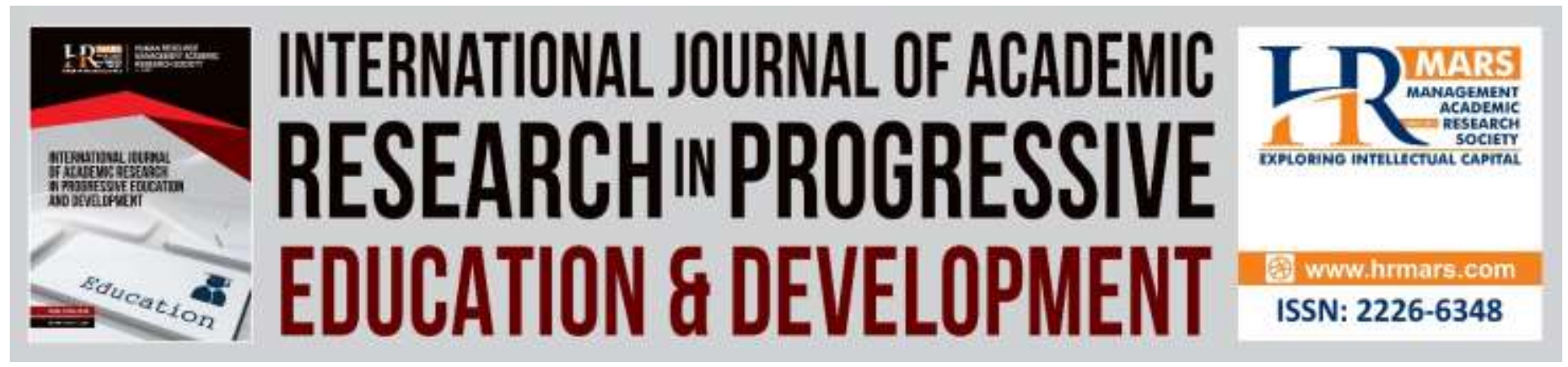

\title{
Digital Game-based Learning in Enhancing Recycling Awareness
}

Lee Siew Chin, Rahimah Wahid

To Link this Article: http://dx.doi.org/10.6007/IJARPED/v9-i2/7300

DOI:10.6007/IJARPED/v9-i2/7300

Received: 15 March 2020, Revised: 30 April 2020, Accepted: 11 May 2020

Published Online: 09 June 2020

In-Text Citation: (Chin \& Wahid, 2020)

To Cite this Article: Chin, L. S., \& Wahid, R. (2020). Digital Game-based Learning in Enhancing Recycling Awareness. International Journal of Academic Research in Progressive Education and Development, 9(2), 269-275.

Copyright: (C) 2020 The Author(s)

Published by Human Resource Management Academic Research Society (www.hrmars.com)

This article is published under the Creative Commons Attribution (CC BY 4.0) license. Anyone may reproduce, distribute, translate and create derivative works of this article (for both commercial and non-commercial purposes), subject to full attribution to the original publication and authors. The full terms of this license may be seen at: http://creativecommons.org/licences/by/4.0/legalcode

Vol. 9(2) 2020, Pg. 269 - 275

http://hrmars.com/index.php/pages/detail/IJARPED

JOURNAL HOMEPAGE

Full Terms \& Conditions of access and use can be found at http://hrmars.com/index.php/pages/detail/publication-ethics 


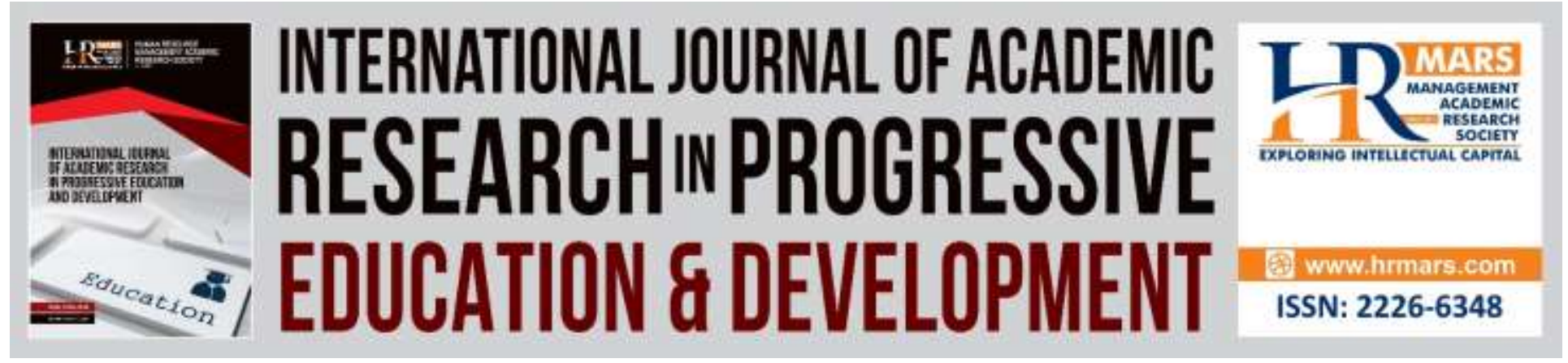

\title{
Digital Game-based Learning in Enhancing Recycling Awareness
}

\author{
Lee Siew Chin, Rahimah Wahid \\ Department of Social Studies and Citizenship, Faculty of Human Science, Sultan Idris Education \\ University, 35900, Tanjong Malim, Perak, Malaysia.
}

\begin{abstract}
This study aims to identify the effect of Edu-Environment digital game in teaching Form 1 students in learning topics about recycling in Seremban secondary school. Quasi-experimental method was applied in this study. The total of 80 students were employed as samples. In this research, students are divided into two different groups which are the controlled and the experimental. Each group is given different treatment where the controlled group is given traditional approach method and the experimental group use the gamification approach method. At the early stage, the two groups of students are given pre-test. The results of the pre-test show there isn't any significant differentiation between the two groups. Based on the findings from the pre-test, controlled group indicated the pre-test with the $\min =9.60$ meanwhile the experimental group indicated the pre-test with the $\min =9.88$. According to the result, experimental group indicated that the scores were significantly higher after playing the game with a $p$-value $=0.00$ and using a level of significance of $0.05(p<0.05)$. This is a statistically significant result which shown there is a statistically significant difference between the scores after playing the game $(M=15.00)$ than the ones before $(M=9.88)$. Therefore, the gamification approach method shows a better improvement in the students' score in the recycling topics compared to the traditional method. Overall, digital game contributed positive impact to government in encouraging teacher using and apply ICT in their teaching lesson. Besides this, this approach also help the students to be more active, increase their self-confidence and their thinking skills.

Keywords: Digital Game, Environment, Experimental Group, Quasi-Experiment, T-Test.

\section{Introduction}

Education is an ongoing effort to develop a holistic student that encompasses the physical, emotional, spiritual, intellectual and social dimensions and all of these aspects are achieved through the process of teaching and learning. Thus, to produce a generation that achieve the national education goals, teachers are the main contributors to innovative and creative teaching and learning. As such, the teaching and learning process is seen as the key to ensuring that students understand the content that teachers want to convey.
\end{abstract}


In order to improve the quality of teaching, teachers have played an important role in encouraging students to develop their minds and thinking skills as well as increase students' confidence to overcome the challenges. Therefore, the creative teaching method is very important in developing students' minds. In conclusion, the use of the internet and computers was strongly encouraged in the 21st Century teaching method. This is because technology not only provides students with the opportunity to explore simulations with applications designed and with the use of internet technology, students can interact with their peers and create learning becomes more interactive. As such, it is undeniable that the application of technology in the education system has brought many positive elements such as encouraging students to prepare for the challenges of the 21st century.

\section{Literature Review \\ Constructivist theory}

In ensuring teaching lesson is carried out more effectively, the theory of learning is an important element. According to Gagné (1985), the purpose of applying theory is to establish a more organized procedure or direction to produce good learning outcomes. Therefore, the theory that are recognized as being relevant to the game-based learning approach in this study is constructivist theory. Based on the constructivist theory, teacher acts as a facilitator which will guide the student learning, simulate and challenge the student's mind in critical thinking, analysis and synthesis throughout the process learning in which the student needs to learn to plan, evaluate and create reflections on their learning. According to Smith-Robbins (2010), the learning approach through gamification are able to encourage students to constantly seek for knowledge in order to satisfy their curiosity and self-esteem. Besides this, students will also learn something new by learning through the experience of mistakes which they had done while playing. In this process, students are no longer receiving knowledge from the instructor directly but organizing, modifying it and build their own knowledge based on the experience gained. In addition, this theory also helps students think and solve the challenges posed by teachers through gaming. According to constructivist theory, students have the ability to create something new based on their own knowledge and their experience. Therefore, students will solve the challenge that exist while playing games.

Several researchers have studied the effects of game-based learning with regards to learning outcomes and motivation levels. Chen, Lin, Looi,Chan (2012) study's indicated that game-based learning had increase students confidence. Besides this, they also indicated that those students who use the digital games "Cross Number Puzzle" have higher levels of motivation and student engagement. This is because digital games can encourage collaboration between students where students can share information and increase engagement in solving problems. Moreover, a study by Cheng, Lou, Kuo, Shih (2013) has shown that digital games allow students to gain more knowledge about environment while playing. They also indicated that students are more enjoyed in learning environment. Besides this, a study by Kasthuri \& Sharifah (2008) found that there are significant differences in students' environmental knowledge before and after the use of experimental simulation games "Recycle City". The findings of this study also show that 
Vol. 9, No. 2, 2020, E-ISSN: 2226-6348@ 2020 HRMARS

there are significant differences in environmental knowledge among Form 4 students regarding environmental and recycling issues.

\section{Research Hypothesis}

Hypothesis 1: There is no significant differences between the achievement scores of the experimental group and the control group in the pre-test for recycling topics.

Hypothesis 2: There is no significant difference between the achievement of control group with experimental group in post-test for recycling topics.

Hypothesis 3: There is no difference between pre-test and post-test for experimental groups for recycling topics.

\section{Methodology}

In this study, the research design used was quantitative method through quasi-experimental design. In conducting this study, researchers have involved two different groups which are experimental groups who using digital games in class lesson while another group is control group which using traditional method in class lesson. There are 40 students playing the digital game in experimental group while 40 students doing traditional learning in control game. According to (Chua,2006), the quasi-experiment is often used when it involves the study of the effectiveness of a teaching method, module or program in a variety of situations that cannot use pure experimental design especially in school situations. In this research, we explored to study the effectiveness of digital games in raising environmental awareness.

\section{Population and Sample}

In this study, the researcher used samples from existing classes without randomly selected respondents. This is because sample random sampling representing experimental groups and control groups is difficult to perform in this study. Moreover, researcher cannot change the gender, race, achievement and student rank in the classroom. Therefore, in this quasiexperimental study, researcher used only two Form 1 classes in the existing without making any changes to student achievement.

\section{Instrument}

Instrument being used in this research is a list of questionnaires containing 31 questions relating to the study that was distributed to respondents to obtain the feedbacks of this study. The set of questionnaire carried the score made with the reference to five Likert scale ranging from 1 (strongly Disagree) to 5 (strongly agree). The data analysis in this study was assisted by using the software "Statistical Packages for Social Science" (SPSS) version 20.0.

\section{Result and Discussion}

The results of the pre- and post-test were collected from the control and experimental groups and analyzed using t-tests in the Statistical Package for Social Science (SPSS) software to test the study hypotheses. The results show that the null hypothesis $(\mathrm{HO})$ is rejected if $\mathrm{p}$ value $<0.05$ 
INTERNATIONAL JOURNAL OF ACADEMIC RESEARCH IN PROGRESSIVE EDUCATION AND DEVELOPMENT

Vol. 9, No. 2, 2020, E-ISSN: 2226-6348 @ 2020 HRMARS

meanwhile hypothesis is accepted if $p$ value $>0.05$. There are 3 hypotheses in this study and the results of the analysis using the t-test are as follows:

Hypothesis 1: There is no significant differences between the achievement scores of the experimental group and the control group in the pre-test for recycling topics.

Table 1. Significant analysis of pre-test for control and experimental groups using independent T-test.

\begin{tabular}{|c|c|c|c|c|c|}
\hline Group & $t$ & $\mathrm{df}$ & $\mathrm{p}$ & Mean & Std.Error Difference \\
\hline Control & -.684 & 78 & .496 & -.275 & .402 \\
\hline Experimental & -.684 & 73.165 & .496 & -.275 & .402 \\
\hline
\end{tabular}

The results in Table 4.1 have shown that the $t$ value is 0.684 with the significant value $p=0.496$ where the significance value is greater than 0.05 ( $p>0.05)$. Therefore, the researchers found that the pre-test for the experimental group and the control group showed that there was no significant difference. Thus, the Ho1 hypothesis that there was no significant difference between the experimental group and the control group in the pre-test for recycling topics was accepted.

Hypothesis 2: There is no significant difference between the achievement of control group with experimental group in post-test for recycling topics.

Table 2 Significant analysis of pasca test for control and experimental groups using independent T-test.

\begin{tabular}{|c|c|c|c|c|c|}
\hline Group & $t$ & $\mathrm{df}$ & $\mathrm{p}$ & Mean & Std.Error Difference \\
\hline Control & -12.669 & 78 & .000 & -5.500 & .434 \\
\hline Experimental & -12.669 & 76.135 & .000 & -5.500 & .434 \\
\hline
\end{tabular}

The results shown in Table 4.2 show that the $t$ of the experimental group was 12.669 same with the control group of 12.669 . Thus, the significant value $(p)$ is $p=0.00$ which means that the significance is less than 0.05 ( $p>0.05$ ). Thus, these findings indicate that there is a significant difference between experimental group and control group in the post-test. Therefore, the Ho2 hypothesis stating that there was no significant difference between the achievement of control group with experimental groups in the post-test of recycling topics was not accepted.

Hypothesis 3: There is no difference between pre-test and post-test for experimental groups for recycling topics.

Table 3. Significant analysis of pre- and post-treatment trials using paired T-test.

\begin{tabular}{|c|c|c|c|c|c|}
\hline Test & Mean & Std.Error & $t$ & $\mathrm{df}$ & $\mathrm{p}$ \\
\hline Pre-Post & -5.125 & 1.505 & -21.532 & 39 & .000 \\
\hline
\end{tabular}


Table 3 shows that the significance level is less than $0.05(p<0.05)$. Thus, it show that there is a significant difference in the achievement of pre- and post-test scores for the experimental group. In addition, the result also shows that experimental groups using Edu-Environment digital games achieved higher scores compared to the control group. Therefore, the Ho3 hypothesis stating that there was no significant difference between the achievement scores of experimental groups using Edu-Environment digital games in pre and post-test for recycling topics was rejected.

\section{Conclusion}

In conclusion, the research conducted has achieved the purpose of the study and the research questions that have been listed by the researcher. In this study, 80 students directly participated in the study and based on the findings, the researchers found that students using digital games have higher achievement than students using traditional methods. This is because the gamification method had motivate students interest as well as has a positive impact on making the learner more active in class lesson. Therefore, this study can be considered successful because it has achieved the objectives. Researcher hope this study will benefit other researchers, especially in the field of education.

\section{Acknowledgement}

The authors would like to thank all individuals and school members who have contributed to this study.

\section{Corresponding Author}

Lee Siew Chin

Faculty of Human Science, Sultan Idris Education University

Email: lee.siewchin1993@gmail.com

\section{References}

Aziz, M., \& Nasir, N. (2012). Pendidikan Alam Sekitar : Melestarikan kesedaran masyarakat di Malaysia. Tanjong Malim: Penerbit Jabatan Geografi Dan Alam Sekitar.

Campbell, D. T., \& Stanley, J. C. (1963). Experimental and quasi-experimental designs for research on teaching. In N. L. Gage (Ed.), Handbook of research on teaching. (pp.171-246), Washington: American Educational Research Association (printed by Rand-McNally).

Cheng, Y. M., Lou, S. J., Kuo, S. H., \& Shih, R. C. (2013). Investigating elementary school students' technology acceptance by applying digital game-based learning to environmental education.. Australasian Journal of Educational Technology, 29(1), 96-110.

Filho, W. L. (1996). An overview of current trends in European environmental education. The journal of Environmental Education. 28(1), 5-10.

Forest, E. (2014). The Addie Model: Instructional Design. Educational Technology website, Frameworks and Theories. Retrieved from https://educationaltechnology.net/the-addie-model-instructional-design/

Fraenkel, J. R., \& Wallen, N. E. (2006). How to design and evaluate research in education. New York: McGraw-Hill. 
INTERNATIONAL JOURNAL OF ACADEMIC RESEARCH IN PROGRESSIVE EDUCATION AND

DEVELOPMENT

Vol. 9, No. 2, 2020, E-ISSN: 2226-6348 @ 2020 HRMARS

Fraenkel, J. R., Wallen, N. E., \& Hyun, H. H. (2012). How to design and evaluate research in education (8th Ed.). New York: McGraw-Hill.

Furdu, I., Tomozei, C., \& Kose, U. (2017). Pros and cons gamification and gaming in classroom. BRAIN. Broad Research in Artificial Intelligence and Neuroscience,8(2): 56-62. Retrieved from https: //www.edusoft/brain/index/article/view.

Gagné, R. M. (1985). The Conditions of Learning and Theory of Instruction. Holt, Rinehart and Winston New York.

Gamifikasi mampu tingkat kualiti aktiviti pengajaran dan pembelajaran. (2016). Arkib Berita UMS. Diperoleh pada Oktober 14, 2016 daripada http://www.ums.edu.my/v5/ms/bannerlink/4895-gamifikasi-mampu-tingkat-kualiti-aktiviti-pengajaran-dan-pembelajaran.

Gamifikasi pendekatan baharu dalam pengajaran mampu tingkat pemahaman pelajar. (2016). Arkib Berita UPM. Diperoleh pada April 15, 2016 daripada http://www.upm.edu.my/berita/gamifikasi_pendekatan_baharu_dalam_pengajaran_ma mpu_tingkat_pemahaman_pelajar-25261.

Hair, Jr., J. F., Money, A. H., Samouel, P., \& Page, M. (2007). Research methods for business. Chichester: John Willey \& Sons Ltd.

Jusuf, H. (2016). Penggunaan gamifikasi dalam proses pembelajaran. Jurnal Technology of Information and Communication, 5(1), 1-6.

Im, T. C., King, E. M., \& Othman, A. R. (2014). Promoting environmental education in Malaysian preschools. Southeast Asia Early Childhood Journal, 3, 12-23.

Kasthuri, V., \& Sharifah, N. S. I. (2008). Pengukuhan pengetahuan dan kesedaran alam sekitar melalui permainan simulasi eksperiential. Malaysian Education Dean's Council Journal, 2 (5).

Likert, R. (1932). A technique for the measurement of attitudes. Archives of Psychology, 140, 155.

Newby, T. J., Stepich, D. A., Lehman, J. D., \& Russell, J. D. (2000). Instructional technology for teaching and learning: designing instruction, integrating computers and using media. New Jersey: Merrill Prentice Hall.

Palmer, J. A. (1998). Environmental education in the $21^{\text {st }}$ century: Theory, practice, progress and promise. New York: Routledge.

Palmer, J. \& Neil, P. (1994). The handbook of environmental education. London: Routledge.

Smith-Robbins, S. (2011). This game sucks": How to improve the gamification of education. EDUCAUSE review, 46(1), 58-59.

Tan, D., Lin, A., \& Kaur, M. (2018). Kahoot! It: Gamification in higher education. Pertanika Journal of Social Science and Humanities. 26 (1): 565 - 582.

Chen, Y.-H., Lin, C.-K. C.-P., Loi, Y. S., \& Chan, T.-W. (2012). A Collaborative Cross Number Puzzle Game To Enhance Elementary Students' Arithmetic Skills, Turkish Online Journal of Educational Technology, 11(2), 1-15.

Aminrad, S. Z., Sayed-Zakariya, A. S. H., \& Sakari, M. (2012). Environmental Education in Malaysia, Progresses and Challenges Ahead. Life Science Journal, 9(2), 1149-1154. 